\title{
Innovative Technology Added Value in Reducing Rice Yield Gap in Tidal Land
}

\author{
Yanter Hutapea* and Fuadi Irsan \\ Assessment Institute for Agricultural Technology of South Sumatra, Indonesia
}

\begin{abstract}
Ameliorant, one of innovative technology, is actually able to accelerate the weathering of rice straw and grass. Other than that, it can also improve soil structure and increase soil $\mathrm{pH}$. This study aims to analyze the added value of using innovative technology in reducing rice yield gaps in tidal land. It involved the Banjar Harum I and Banjar Sari Farmer Groups in Pinang Banjar Village, Sungai Lilin District, Musi Banyuasin, South Sumatra during the dry season of 2020 in an area of 45 ha. The ameliorant used was 5 liter/ha of bio-decomposer and 1 t/ha lime (dolomite). The results showed that the application of bio-decomposer and dolomite produced 3,617 and 3,283 kg/ha Harvested Dry Grain (HDG) respectively of the farmer groups as compared to $1,700 \mathrm{~kg} / \mathrm{ha}$ of local farmers using no ameliorant. The added value of the innovative technology use is IDR 9,126,000 and IDR 7,408,440/ha, with MBCR of 2.15 and 1.25, respectively. In the wet season of 2020 , the use of bio-decomposers and dolomite can reduce yield gaps by 17.74 and $14.38 \%$, respectively, with the potential productivity of Inpari 42.
\end{abstract}

\section{Introduction}

More than half of the world's population consumes rice as a staple food [1;2]. Therefore, the availability of rice is prioritized. The increasing of rice production will not be sufficient if only rely on irrigation land, new land clearing on suboptimal land will be required. The development of tidal swamp land is a strategic step taken by the government considering its enormous potential, but it has not been utilized optimally. Reclamation of tidal swamp land is carried out to produce food, especially rice by utilizing its potential optimally, improving water management, and revitalizing existing infrastructure [3]. Tidal swamp area has a significant contribution to food production since, of the 774,502 ha of rice fields in South Sumatra, 273,919 ha is tidal swamp land, which ranks second after non-tidal rice fields.

Insufficient management problems in production systems are common, such as the usage of production facilities, particularly those constructed of chemicals, and the lack of needs-based technology that is adapted to local ecosystems in pest and disease control [4]. The excessive use of inorganic fertilizers and agrochemicals not only increases the production of food and other agricultural products but also has effect on land degradation, environmental problem, and increased yield losses due to pests and diseases. The use of unbalanced chemical fertilizers can increase the intensity of pest and disease attacks on rice

\footnotetext{
*Corresponding author: hutapeayanter@yahoo.co.id
} 
plants which causes yield losses of around 15-30\% [5]. Excessive chemical use in tidal swamp area puts food security, particularly rice, at risk, also threatens the sustainability of the rice production system. Rice production in tidal swamp area can potentially become untenable as a result of this [6]. Farmers' perception, poor knowledge, and behavioral aspect are all factors that influence the impact of utilizing these chemicals [7]. Of course, the tidal agro ecosystem with its constraints and problems needs to be minimized so that the specified output can be achieved. Therefore, to protect the environment while improving rice productivity to meet the ever-growing demand, careful management of rice ecosystem functions, the use of technology, infrastructure, and policies must be updated and embraced [8].

A bio intensive approach by incorporating ecological and economic factors into agricultural systems to address public concerns about environmental quality and food safety is explored as a sustainable approach [9]. Returning crop residues is one way to maintain organic matter content while also reducing soil fertility loss caused by planting. Rice straw is a waste of agriculture that can be used as an organic material. During the harvest season, rice straw is abundant. If the average grain yield is 5 tons/ha, then 1 ha yields 7.5 tons of straw (assuming ratio of grain with straw is 2:3). Straw is a comprehensive source of macro and micronutrients. Straw waste comprises $30-40 \% \mathrm{C}, 1.5 \% \mathrm{~N}, 0.3 \% \mathrm{P}_{2} \mathrm{O} 5,2 \% \mathrm{~K}_{2} \mathrm{O}$, and $0.3 \% \mathrm{SiO}_{2}$, as well as micronutrients such as $\mathrm{Cu}, \mathrm{Zn}, \mathrm{Mn}, \mathrm{Fe}, \mathrm{Cl}$, and $\mathrm{Mo}$ [10].

Nutrient management, including balanced fertilization and the application of ameliorants, is required to support land management. One way that can be applied is the use of microbial decomposers as an effort to increase rice productivity by improving the physical, chemical and biological conditions of the soil. Increased production can also be achieved by minimizing the yield gap, which can be accomplished through the use of innovative technologies [11]. Yield gaps can be caused by a various problem, including biophysical (water availability, soil fertility), technical, socio-economic, and institutional factors. Yield gaps are discussed not only as an attempt to explain the effects of factors that can increase, limit and reduce actual yields but also as an effort to improve the livelihoods of people in rural areas [12]. Furthermore, this study aims to analyze the added value of using innovative technology in reducing rice yield gaps in tidal land. The results of this study can be used to reduce rice yield gaps in other agro ecosystems.

\section{Methodology}

Table 1. Existing rice cultivation technology in Pinang Banjar Village, Sungai Lilin District, Musi Banyuasin Regency

\begin{tabular}{|l|l|}
\hline \multicolumn{1}{|c|}{ Component } & \multicolumn{1}{c|}{ Description } \\
\hline Land management & $\begin{array}{l}\text { The remaining plants in paddy fields were sprayed with herbicide at a dose } \\
\text { of 4-5 1/ha. The land is cultivated using a tractor. }\end{array}$ \\
\hline Water management & $\begin{array}{l}\text { Micro water management (repair of quarter drainage, perimeter drainage), } \\
\text { generally do not use small trenches }\end{array}$ \\
\hline Use of Organic Ingredients & Return of straw to paddy fields evenly. \\
\hline Planting system & Scatter \\
\hline Variety & Mekongga and Ciherang \\
\hline Seed Volume & $50-60 \mathrm{~kg} / \mathrm{ha}$ \\
\hline Fertilizer Dosage & Urea $100 \mathrm{~kg} / \mathrm{ha}, \mathrm{KCl} 50 \mathrm{~kg} / \mathrm{ha}$, TSP $50 \mathrm{~kg} / \mathrm{ha}$ \\
\hline Fertilization Method & $\begin{array}{l}\text { Spread evenly, urea is given once at } 21-25 \text { days after sowing, and } \mathrm{KCl} \text { is } \\
\text { given before the rice generative phase }\end{array}$ \\
\hline Pest control & Pests'visualization and mixes of several types of ingredients \\
\hline Weed control & Selective and manual use of herbicides \\
\hline Harvest and post-harvest & $\begin{array}{l}\text { Harvest is after the grain is fully ripe }(90 \%) . \text { Using combined harvesters. } \\
\text { Drying of grain using tarpaulin. }\end{array}$ \\
\hline
\end{tabular}


This study was carried out in Pinang Banjar Village, Sungai Lilin District, Musi Banyuasin Regency, South Sumatra during the dry season (June-September) 2020. The area under study was a land plot of 45 ha with three hectares of focus plots for technology control. The observed plots applied the technological innovations using Bio decomposers and dolomite. Both were compared with those of local farmers. The existing technology at the study site is described in Table 1.

The innovative technology to improve the way of rice cultivation by farmers is the use of ameliorant, as shown in Table 2.

Table 2. Rice Cultivation Innovative Technology in Pinang Banjar Village, Sungai Lilin District, MusiBanyuasin Regency, in the dry season of 2020.

\begin{tabular}{|l|l|}
\hline \multicolumn{1}{|c|}{ Component } & \multicolumn{1}{c|}{ Description } \\
\hline Land management & Land is cultivated using tractors. \\
\hline Use of Organic Material & Return of straw to paddy fields evenly. \\
\hline $\begin{array}{l}\text { Use of ameliorant } \\
\text { Dolomite-enhanced plot }\end{array}$ & $\begin{array}{l}\text { The remaining plants in paddy fields were sprayed with herbicides (4 } \\
\text { 1/ha). Giving dolomite 1 t/ha, during land cultivation }\end{array}$ \\
\cline { 2 - 2 } $\begin{array}{l}\text { Biodecomposer-enhanced } \\
\text { plots }\end{array}$ & $\begin{array}{l}\text { Use of biodecomposer (Beka) } 5 \text { 1/ha, } \\
\text { 2 weeks before planting }\end{array}$ \\
\hline Water management & $\begin{array}{l}\text { Micro water management (repair of quarter, perimeter and worms' } \\
\text { ditches) }\end{array}$ \\
\hline Planting system & Scatter \\
\hline Varieties & VUB Inpari 42 \\
\hline Seed volume & $50 \mathrm{~kg} /$ ha \\
\hline Fertilization dose & Based on Swamp Soil Test Equipment and leaf color chart (LCC) \\
\hline Fertilization Method & $\begin{array}{l}\text { Spread evenly. Urea (300 kg/ha) and KCl (125 kg/ha) were given 2 half } \\
\text { doses, 2 weeks after sowing and 1 month after the first fertilization. TSP } \\
(120 \mathrm{~kg} / \text { ha) was applied at the time of the first fertilization }\end{array}$ \\
\hline Pest control & $\begin{array}{l}\text { With an integrated IPM approach (based on the type of pest and attack } \\
\text { level) }\end{array}$ \\
\hline Weed control & Selective and manual use of herbicides \\
\hline $\begin{array}{l}\text { Harvest/post-harvest } \\
\text { handling }\end{array}$ & $\begin{array}{l}\text { Harvesting is done after the grain is fully ripe (90\%). Using combine } \\
\text { harvesters. Drying of grain using tarpaulin and artificial drying (box } \\
\text { dryer) }\end{array}$ \\
\hline
\end{tabular}

*) each ameliorant is given in a separate plot

The data observed include the productivity of Harvested Dry Grain (HDG) and inputs used, input and output prices, costs incurred, farm income, factors causing yield gaps. The data obtained were tabulated and analyzed descriptively. The rice yield gap between several yield levels is calculated with the following formula:

$$
\begin{gathered}
\Delta Y_{\mathrm{a}}=Y_{1}-Y_{0} \\
\Delta Y_{\mathrm{a}}(\%)=\Delta Y_{\mathrm{a}} / Y_{0} \times 100 \%
\end{gathered}
$$

Where,

$\Delta Y_{\mathrm{a}}=$ yield gap between existing technology and assessment result $(\mathrm{t} / \mathrm{ha})$

$Y_{0}=$ existing productivity $(\mathrm{t} / \mathrm{ha})$

$Y_{1}=$ productivity of assessment result $(\mathrm{t} / \mathrm{ha})$

The same method can be used to calculate the increase in income. Furthermore, business feasibility will be calculated using Revenue Cost Ratio (R/C) and the feasibility of the innovation carried out compared to the previous method using Marginal Benefit Cost Ratio (MBCR) [13]. 


$$
\frac{R}{C}=\frac{T R}{T C}=\frac{Q \cdot P q}{\sum_{i=1}^{n} X i \cdot P X i}
$$

Where,

TR = Total Revenue

$\mathrm{TC}=$ Total Cost

$\mathrm{Q}=$ Quantity of production

$\mathrm{Pq}=$ Price of production

$\mathrm{Xi}=$ Input type

Pxi $=$ Price of input type

$\mathrm{i} \quad=1,2 \ldots \ldots . \mathrm{n}$

$$
M B C R=\frac{B 1-B 2}{C 1-C 2}
$$

Where,

$\mathrm{B}=$ Benefit

$\mathrm{C}=$ Production cost

$1=$ New method

$2=$ Old method

Decision method:

$\mathrm{R} / \mathrm{C}>1$, the farming business is economically profitable

$\mathrm{R} / \mathrm{C}<1$, the farming business is economically experiencing a loss

MBCR $>1$ (The introduced technology is feasible),

MBCR $<1$ (The introduced technology is unfeasible)

\section{Results and Discussion}

\subsection{Rice Farming Production and Efficiency}

The amount of production costs is influenced by the amount of input used such as fertilizer. Based on the analysis of the elements N, P, K, lime and soil pH carried out at the South Sumatra AIAT laboratory using the Swamp Soil Test Equipment, the following results were obtained

Table 3. Results of soil sample analysis using the Swamp Soil Test Equipment in Pinang Banjar Village, Sungai Lilin District, Musi Banyuasin Regency in the dry season of 2020.

\begin{tabular}{|l|c|c|}
\hline Parameter & Value & Recommendation \\
\hline $\mathrm{pH}$ & $\mathrm{pH}-5$ & $500 \mathrm{~kg} / \mathrm{ha}$ \\
\hline lime & $<4$ & $300 \mathrm{~kg} / \mathrm{ha}(\mathrm{urea})$ \\
\hline $\mathrm{N}$ & low & $150 \mathrm{~kg} / \mathrm{ha}(\mathrm{SP} 36)$ \\
\hline $\mathrm{P}$ & low & With straw $2.5 \mathrm{t} / \mathrm{ha}=125 \mathrm{~kg} / \mathrm{ha}(\mathrm{K} \mathrm{Cl})$ \\
$\mathrm{K}$ & low & Without straw $=150 \mathrm{~kg} / \mathrm{ha}(\mathrm{K} \mathrm{Cl})$
\end{tabular}

The use of SP 36 was replaced with TSP because this activity did not use subsidized fertilizers. The dose was $120 \mathrm{~kg} / \mathrm{ha}$, while $\mathrm{KCl}=125 \mathrm{~kg} / \mathrm{ha}$ with the consideration of even return of rice straw.

The analysis results indicated that dolomite use has higher production costs compared to bio-decomposer due to its higher value. Meanwhile, labor costs are higher in the use of bio- 
decomposers, due to higher production resulting in higher harvest/post-harvest costs.

The application of bio-decomposers generates a net income of IDR 6,574,700/ha, of dolomitegenerates net income of IDR 3,180,790/ha, and of without ameliorant only provides an income of IDR 1,677,180/ha. It is more efficient than the other two methods indicated by a higher $\mathrm{R} / \mathrm{C}$ value. Theuse of bio-decomposers and dolomite have MBCR values of 2.15 and 1.25 , respectively. The added value of the use of biodecomposers and dolomite is IDR. 9,126,000/ha and IDR. 7,408,440/ha, accordingly (simplified from Appendix 1).

Table 4. Costs and added value of rice cultivation innovative technology in Pinang Banjar Village, Sungai Lilin District, Musi Banyuasin Regency in the dry season of 2020.

\begin{tabular}{|l|c|c|c|}
\hline \multirow{2}{*}{ Item } & \multicolumn{2}{|c|}{ Innovative Technology } & \multirow{2}{*}{ Farmer's practice } \\
\cline { 2 - 3 } & Biodecomposer & Dolomith & \\
\hline Material cost (IDR/ha) & $3,940,500$ & $5,800,500$ & $2,253,000$ \\
\hline Labor cost (IDR/ha) & $6,566,800$ & $6,383,150$ & $4,025,820$ \\
\hline Total cost (IDR/ha) & $10,507,300$ & $12,183,650$ & $6,278,820$ \\
\hline HDG productivity (kg/ha) & 3.650 & 3.283 & 1.700 \\
\hline Revenue (IDR/ha) & $17,082,000$ & $15,364,440$ & $7,956,000$ \\
\hline Income (IDR/ha) & $6,574,700$ & $3,180,790$ & $1,677,180$ \\
\hline R/C & 1.62 & 1.26 & 1.26 \\
\hline MBCR & 2.15 & 1.25 & \\
\hline Value added (IDR/ha) & $9,126,000$ & $7,408,440$ & \\
\hline
\end{tabular}

The results showed that the productivity of HDG using bio-decomposers and dolomite was 3.65 and $3.28 \mathrm{t} / \mathrm{ha}$, respectively. On the other hand, no ameliorant (farmer's practice) was $1.7 \mathrm{t} / \mathrm{ha}$. Bio-decomposers (BEKA) uses superior microbes to decompose organic matter which can degrade organic matter more quickly, fertilize the soil, and absorb toxic compounds $(\mathrm{Al}+, \mathrm{Fe}+, \mathrm{Mn} 2+, \mathrm{H} 2 \mathrm{~S})$ so as to improve soil $\mathrm{pH}$ without using agricultural lime. The results of the study in the tidal rice fields of Sungai Daun Village, Selakau District, East Kalimantan showed that the application of ameliorants such as biochar, chicken manure and dolomite resulted in Milled Dry Grain (MDG) of 5.76, 4.32 and 4.30 t/ha, respectively. Furthermore, the control's (without ameliorant) result was 2.27 t/ha [14].

\subsection{Yield Gap Analysis}

Yield gap analysis was carried out by distinguishing yields into three groups, namely: potential yields in very ideal conditions, experimental results and actual yields of farmers [11]. Other study added another yield criterion: the farmer's potential yield (its position between the farmer's actual yield and the experimental result) [15]. The sum of the yield gaps between the several types results the total yield gap. The determination of the yield group can be carried out in one particular area, it can be a village, sub-district or wider area. The result gap in this study uses unhulled rice which is converted to $83.38 \%$ of harvest crop grain. The observation area is limited to Pinang Banjar Village.

The determination of the yield group can be carried out in one particular area, either it is village, sub-district or wider area. The yield gap in this study uses milled dry grain (MDG) which is processed to $83.38 \%$ of Harvested Dry Grain (HDG). The observation area was limited in the village of Pinang Banjar.

1. Determination of the actual yield of farmers is obtained from the average yield of farmers in the study area. These resultsare not based on certain varieties but from the actual results obtained by farmers. The actual average productivity is $1,417 \mathrm{t} / \mathrm{ha}$ of MDG 
2. Rice yield as a result of the assessment in an area can be done through demonstration plots with technological innovations application. The innovations using biodecomposers and dolomite resulted in yield of 3,043 and 2,736 t/ha HDG, respectively.

3. The potential yield of Inpari 42 based on its description under very ideal conditions is $10.58 \mathrm{t} / \mathrm{ha}$ HDG.

The yield gap between the actual rice productivity of farmers and the results of the study using innovative technology with the provision of biodecomposers and dolomite was 53.43 and $48.20 \%$, respectively. The gap between the results of the study using a biodecomposer and the potential yield of Inpari 42 is $71.23 \%$, while the gap between the results of the study using dolomite and the potential yield of Inpari 42 is $74.14 \%$. The yield gap between farmers' actual rice productivity and the potential yield of Inpari 42 is $86.60 \%$. Thus, in the dry season in Pinang Village, Banjar District, Kec. Sungai Lilin using innovation technology with the provision of biodecomposers and dolomite can reduce yield gaps by 17.74 and $14.38 \%$, respectively, with the potential productivity of Inpari 42 .

Identification of the causes of the yield gap between farmers' actual rice productivity and the results of the study using ameliorant indicates that the factors causing the gap are: 1) the limited capital capacity of farmers in providing inputs, 2) limited skills of farmers in cultivating, 3) untimely availability of production inputs, 4) incorrect use of infrastructure for rice production, especially the type and dosage, 5) pest attacks: rats and birds in the plantation, and 6) Uncertified varieties. The results of the study using ameliorant with the potential yield of these varieties are: 1) activities carried out in the dry season, 2)availability of water, relatively unregulated, 3) differences in agroecosystems, 4) pets, especially rats and birds.

\section{Conclusions}

The use of innovative technology with the provision of bio decomposers and dolomite, resulted in the yield of HDG Inpari 42 at the dry season of 2020 at 3,650 and 3,283 $\mathrm{kg} / \mathrm{ha}$, respectively, while the farmer method was $1,700 \mathrm{~kg} / \mathrm{ha}$ (Mekongga and Ciherang). Compared to the farmer's method (without ameliorant), the use of biodecomposers and dolomite provides added value of IDR 9,126,000/ha and IDR 7,408,440/ha, respectively. Innovative technology with the provision of biodecomposers and dolomite can reduce yield gaps by 17.74 and $14.38 \%$, respectively, with the potential yield of Inpari 42 .

Acknowledgements. All of the author are the main contributor. Thanks to the head of Banjar Harum I and Banjar Sari Farmers Group in Pinang Banjar Village, Sungai Lilin District, Musi Banyuasin, South Sumatra for the information provided.

\section{References}

1. Rao, D.S., Neeraja,C.N M.Babu, P., Nirmala,B., Suman, K., and L.V.S. Rao. Front. Nutr. 7:26. doi:10.3389/fnut.2020.00026 (2020)

2. Tripathy, S. K and A. Bala. Plant Biol Crop Res. 4 (1): 1032. (2021)

3. Sulaiman A.A., Y. Suleman and B. Minasny. Resources 8, 34; doi:10.3390/ resources 8010034 (2019)

4. Rao A.N., S.P. Wani, M.S. Ramesha, and J.K. Ladha. In B.S. Chauhan et al. (eds.), Rice Production Worldwide. Springer International Publishing. DOI 10.1007/978-3319-47516-5_8(2017) 
5. Simarmata T, Hersanti, T. Turmuktini, B.N. Fitriatin, M.R. Setiawati and Purwanto. Hayati Journal of Biosciences 23:181-184 (2016)

6. Purba K.F., M. Yazid, M. Hasmeda, D. Adriani, and M.F. Tafarini. Potravinarstvo Slovak Journal of Food Sciences. 15: 9-17. https://doi.org/10.5219/1473 (2021)

7. Jallow, M.F.A., Awadh, D.G., Albaho,M.S., Devi,V.Y., and B.M. Thomas. 2017. Science of the Total Environment. 574:.490-498. https://doi.org/10.1016/ j.scitotenv. 2016.09.085. (2017)

8. Pathak H., P. Samal and M. Shahid. In Pathak et al., The Indian Council of Agricultural Research ( ICAR)-National Rice Research Institute Cuttack, Odisha, India. (2018)

9. Mukherjee, A.K., M.K. Bag, M. Annamalai, T. Adak, S. Lenka, Basanagowda G., Prasanthi G, Raghu S, M. Baite, Prabhukarthikeyan SR, N.B. Patil, P.C. Rath, Guru Prasanna Pandi G, S.R.R. Korada, N. Basak, U. Kumar, S.D. Mohapatra, S. Bhagat, A. Banerjee, R. Bhagawati and M. Jena. In Pathak et al., Rice Research For Enhancing Productivity, Profitability and Climate Resilience. The Indian Council of Agricultural Research (ICAR)-National Rice Research Institute Cuttack, Odisha, India. (2018)

10. Wahyuni, S.E.T., dan A. Asngad. Prosiding Seminar Nasional Pendidikan Biologi dan Saintek II. Surakarta, 20 Mei (2017)

11. Silva J. V and J.J. Ramisch. Experimental Agriculture: 1-28. Doi:10.1017/S001447 97 180 00236. (2018)

12. Dzanku, F. M., M. Jirstrom and H. Marstorp. World Development 67:336-362 (2015)

13. Hendayana R. Analisis Data Pengkajian. IAARD Press, Badan Litbang Pertanian, Jakarta. (2016)

14. Hatta and Sulakhudin. International Seminar and Congress of Indonesian Soil Science Society. IOP Conf. Series: Earth and Environmental Science 393 (2019) 012038 (2019)

15. Liu Z., X. Yang, X. Lin, K. G. Hubbard, Shuo Lv and J. Wang. Science of the Total Environment 541:756-764. (2016) 
Appendix 1. Costs, revenues and income of rice farming by using ameliorant and farmers practice in Pinang Banjar Village, Sungai Lilin Sub Distret, Musi Banyuasin Regencies in the dry season of 2020

\begin{tabular}{|c|c|c|c|c|c|c|c|c|c|c|}
\hline \multirow{3}{*}{$\begin{array}{l}\text { No. } \\
\text { A }\end{array}$} & \multirow{3}{*}{$\begin{array}{l}\text { Item } \\
\text { Material/tool }\end{array}$} & \multicolumn{3}{|c|}{ Biodekomposer } & \multicolumn{3}{|c|}{ Dolomit } & \multicolumn{3}{|c|}{ Farmer's practice } \\
\hline & & \multicolumn{2}{|c|}{ Volume } & \multirow[t]{2}{*}{ Value(IDR) } & \multicolumn{2}{|c|}{ Volume } & \multirow[t]{2}{*}{ Value(IDR) } & \multicolumn{2}{|c|}{ Volume } & \multirow[t]{2}{*}{ Value(IDR) } \\
\hline & & & & & & & & & & \\
\hline 1. & Seed & 40 & $\mathrm{~kg}$ & 400,000 & 40 & $\mathrm{~kg}$ & 400,000 & 50 & $\mathrm{~kg}$ & 500,000 \\
\hline 2. & Urea & 300 & $\mathrm{~kg}$ & 750,000 & 300 & $\mathrm{~kg}$ & 750,000 & 100 & $\mathrm{~kg}$ & 250,000 \\
\hline 3. & TSP & 120 & $\mathrm{~kg}$ & 960,000 & 120 & $\mathrm{~kg}$ & 960,000 & 50 & $\mathrm{~kg}$ & 400,000 \\
\hline 4. & $\mathrm{KCl}$ & 125 & $\mathrm{~kg}$ & 937,500 & 125 & $\mathrm{~kg}$ & 937,500 & 50 & $\mathrm{~kg}$ & 375,000 \\
\hline 5. & Ameliorant & 5 & liter & 375,000 & 1,000 & $\mathrm{~kg}$ & $2,000,000$ & & & \\
\hline 6. & Herbicide & & & 200,000 & & & 450,000 & & & 450,000 \\
\hline 7. & Insekticide & & & 150,000 & & & 150,000 & & & 200,000 \\
\hline 8. & Sack & 56 & sheet & 168,000 & 51 & sheet & 153,000 & 26 & sheet & 78,000 \\
\hline B & Labor & & & & & & & & & \\
\hline 1. & Land cultivation & & & $1,000,000$ & & & $1,000,000$ & & & $1,000,000$ \\
\hline 2. & Seed broadcast & & & 140,000 & & & 140,000 & & & 140,000 \\
\hline 3. & Refilling gaps for the missing hills & & & 140,000 & & & 140,000 & & & 140,000 \\
\hline 4. & Fertilization & 1.5 & mandays & 210,000 & 1.5 & mandays & 210,000 & 1 & mandays & 140,000 \\
\hline 5. & Ameliorant application & 0.5 & mandays & 70,000 & 2 & mandays & 280.000 & & & \\
\hline 6. & Herbicide application before planting & & & & 0.5 & mandays & 70,000 & 0.5 & mandays & 70,000 \\
\hline 7. & Herbicide application after planting & 0.3 & mandays & 42,000 & 0.3 & mandays & 42,000 & 0.3 & mandays & 42,000 \\
\hline 8. & Pest and disease control & 0.28 & mandays & 40,000 & 0.28 & mandays & 40,000 & 0.28 & mandays & 40,000 \\
\hline $\mathrm{C}$ & Production sharing (HDG) & 521.4 & $\mathrm{~kg}$ & & 469 & $\mathrm{~kg}$ & & 242.85 & $\mathrm{~kg}$ & \\
\hline $\mathrm{D}$ & Production sharing (rice equivalent) & 271.1 & $\mathrm{~kg}$ & $2,439,900$ & 243.88 & $\mathrm{~kg}$ & $2,194,920$ & 126.28 & $\mathrm{~kg}$ & $1,136,520$ \\
\hline E & Consumption cost for harvesters & & & 300,000 & & & 300,000 & & & 300,000 \\
\hline $\mathrm{F}$ & Production of HDG & 3,650 & $\mathrm{~kg}$ & & 3,283 & $\mathrm{~kg}$ & & 1,700 & $\mathrm{~kg}$ & \\
\hline G. & Transportation costs & 48.1 & sack & 240,500 & 43.29 & sack & 216,450 & 22.4 & sack & 112,000 \\
\hline $\mathrm{H}$. & Sun drying & 48.1 & sack & 481,000 & 43.29 & sack & 432,900 & 22.4 & sack & 224,000 \\
\hline I. & Production sharing with Rice Milling Unit & 162.6 & $\mathrm{~kg}$ & $1,463,400$ & 146.32 & $\mathrm{~kg}$ & $1,316,880$ & 75.7 & $\mathrm{~kg}$ & 681,300 \\
\hline J. & Revenue & 1,898 & $\mathrm{~kg}$ & $17,082,000$ & $1,707.16$ & $\mathrm{~kg}$ & $15,364,440$ & 884 & $\mathrm{~kg}$ & $7,956,000$ \\
\hline $\mathrm{K}$. & Material/tool cost & & & $3,940,500$ & & & $5,800,500$ & & & $2,253,000$ \\
\hline L. & Labor cost & & & $6,566,800$ & & & $6,383,150$ & & & $4,025,820$ \\
\hline $\mathrm{M}$ & Total production cost & & & $10,507,300$ & & & $12,183,650$ & & & $6,278,820$ \\
\hline $\mathrm{N}$. & Income & & & $6,574,700$ & & & $3,180,790$ & & & $1,677,180$ \\
\hline
\end{tabular}

